\title{
Islam in the African-American Experience
}

\author{
Richard Brent Turner \\ Bloomington and Indianapolis: \\ Indiana University Press, 2003, 2d ed. 312 pages.
}

Islam in the African-American Experience is a historical account of Islam in the African-American community. Written by a scholar of AfricanAmerican world studies and religious studies, this book focuses on the interconnection between African Americans' experiences with Islam as it developed in the United States. While this scholarly work is invaluable for students and professors in academia, it is also a very important contribution for anyone seriously interested in Islam's development in this country. Moreover, it serves as a central piece in the puzzle for Muslims anxious to understand Islam's history in the United States and the relationship between African-American and immigrant Muslims. The use of narrative biographies throughout the book adds to its personal relevance, for they relate the personal history of ancestors, known and unknown, to Islam's history in this country. Turner's work furthers African-American Muslims' journey toward unlocking their history.

The main concept expressed in Turner's book is that of signification, the issue of naming and identity among African Americans. Turner argues that signification runs throughout the history of Islam among African Americans, dating back to the west coast of Africa, through the Nation of Islam, to many of its members' conversion to orthodox Sunni Islam, and through Islamic messages disseminated via contemporary hip-hop culture. According to Turner, Charles Long refers to signification as "a process by which names, signs and stereotypes were given to non-European realities and peoples during the western conquest and exploration of the world” (p. 2). The renaming of Africans by their oppressors was a method of dehumanization and subjugation.

The author argues that throughout the history of African-American Muslims, Islam served to "undercut signification by offering African Americans a chance to signify themselves" (p. 3). Self-signification is an antithesis to the oppressive use of signification, for it facilitates empowerment and growing independence from the dominant group. In addition, "signification involved double meanings. It was both a potent form of oppression and a potent form of resistance to oppression” (p. 3). By choosing Muslim names, whether they were Muslim or not, Turner claims that 
African Americans made a statement about their identity - political, cultural, or religious.

This book, a major contribution to our understanding of the development of African-American Muslim identity formation, is divided into three sections: an "Introduction to the Second Edition," "Root Sources," and "Prophets of the City." The first section explores the impact of the 9/11 tragedy on Muslims in the United States. Turner considers the growth of Islamophobia, the rise of hate crimes, and the use of federal legislation to legitimize civil rights violations against Muslims and promote the erosion of civil liberties by exploring how African-American Muslims have been impacted. This introduction also explores Islam's impact on contemporary culture among African Americans. Jazz and hip-hop culture have been influenced by Islam and, conversely, these musical genres have served as an impetus for the spread of Islam in this country and throughout its urban centers. Additionally, it acknowledges the divide between African-American and immigrant Muslims, which was highlighted as a result of the 2001 election of George W. Bush and the post-9/11 era of discrimination faced by immigrant Muslims. Such a situation, however, has been a long-standing experience for all African Americans - regardless of their religion.

The next section, "Root Sources," provides a comprehensive and detailed history of Muslims of African descent in the United States from the trans-atlantic slave trade through the twentieth century. In this section, Turner tells the stories of such African Muslims as Estevan, the Moroccan guide, interpreter, and explorer who is the first identifiable Muslim in North America. We learn how Muslim Africans maintained their religious and ethnic identities during slavery from the stories of Abd al-Rahman Ibrahima, Omar ibn Said, Lamine Kaba (Kebe), Yarrow Mamout, Bilali Mohamed, and Salih Bilali. Turner suggests that preserving their African names, religious clothing and practices, and ethnic/tribal identities helped African Muslims maintain their identity and resist the institution of slavery.

The final section, "Prophets of the City," tells the stories of AfricanAmerican Muslims who coexisted with immigrant Muslims in American urban centers. Here, Turner looks at urbanization, migration, and immigration as key factors that helped sensitize African Americans to Islam in the early 1900s. First, he argues that the Great Migration from the South to the northern urban centers during the first half of the twentieth century served as a "link to global Islam because urbanization is a context for understanding signification and identity in West Africa and Black America” (p. 73). Second, because the first African-American-based Islamic movements orig- 
inated in the cities, urbanization is an important factor. And third, it is in the urban centers that immigrant Muslims and African Americans converged and forged the link to global Islam and opportunities, missed or taken, to reintroduce African Americans to Islam.

This section also discusses the little-known role of the Ahmadiyah Mission in introducing African Americans to Islam and presenting a multiracial model of Islam in the United States. Turner also discusses signification and identity as it relates to Marcus Garvey's Pan-African movement, Noble Drew Ali's Moorish Science Temple, the Nation of Islam, the Darul Islam community, Sufi paths, and Warith Deen Muhammad's community. Key figures in Islam's development among African Americans (e.g., Elijah Muhammad, El Hajj Malik El Shabazz [a.k.a. Malcolm X], Warith Deen Muhammad, Wali Akram of Cleveland, and Sheik Daoud Ahmed Faisal of Brooklyn's State Street Mosque) are also shared with readers.

Islam in the African-American Experience is a well organized, yet fluid, account of the early historical background necessary to prepare readers to understand the more contemporary issues of signification among AfricanAmerican Muslims. Turner weaves the concepts of signification and identity throughout the book, masterfully making the connection to historical periods and personalities. His book is a valuable contribution to the literature about Islam in the United States and, more specifically, to our understanding of the historical and contemporary identity formation and maintenance of religious identity among Muslims of African decent in a society that has institutionalized racism and vilified Islam. Turner has successfully connected global Islam, Islam in the United States, and the experience of African-American Muslims in this cutting-edge historical piece.

Aneesah Nadir Assistant Professor, Department of Social Work, College of Human Services Arizona State University at the West Campus, Phoenix, Arizona President, Islamic Social Services Association - U.S.A. 